\title{
Pollination efficiency of the stingless bee Melipona subnitida on greenhouse sweet pepper
}

\author{
Darci de Oliveira Cruz $^{(1)}$, Breno Magalhães Freitas ${ }^{(1)}$, Luis Antônio da Silva ${ }^{(1)}$, Eva Mônica Sarmento da Silva ${ }^{(1)}$ \\ and Isac Gabriel Abrahão Bomfim(1)
}

(1)Universidade Federal do Ceará, Dep. de Zootecnia, Caixa Postal 12168, Campus do Pici, CEP 60021-970 Fortaleza, CE. E-mail: freitas@ufc.br

\begin{abstract}
The present study was carried out in Northeastern Region of Brazil, in order to investigate the use of stingless bee Melipona subnitida Ducke in the pollination of greenhouse sweet pepper (Capsicum annuum L.). Treatments of hand cross-pollination, hand self-pollination, pollination by bees and restricted pollination were performed. Results showed that despite sweet pepper flowers are considered autogamous, this crop benefits from pollination by $M$. subnitida, producing fruits significantly heavier and wider, containing a greater number of seeds and of better quality (lower percentage of malformed fruits) than self-pollinated sweet pepper. Thus, M. subnitida can be considered an efficient pollinator of greenhouse sweet pepper.
\end{abstract}

Index terms: meliponin, caged environment, sweet pepper flower.

\section{Eficiência de polinização da abelha sem ferrão Melipona subnitida na cultura do pimentão em casa de vegetação}

\begin{abstract}
Resumo - O objetivo deste trabalho foi investigar o uso da abelha sem ferrão Melipona subnitida Ducke, na polinização de flores de pimentão (Capsicum annuum L.), sob cultivo protegido, na Região Nordeste do Brasil. Foram comparados tratamentos de polinização cruzada manual, polinização por abelhas, autopolinização manual e polinização restrita. Os resultados mostraram que apesar de as flores de pimentão serem consideradas autógamas, essa cultura beneficia-se da polinização realizada por $M$. subnitida, produzindo frutos significativamente mais pesados e mais largos, com um número maior de sementes e de melhor qualidade (baixo porcentual de frutos deformados), quando comparada com a cultura autopolinizada. Portanto, M. subnitida pode ser considerada uma polinizadora eficiente de pimentão em casa de vegetação.
\end{abstract}

Termos para indexação: meliponineos, cultivo protegido, flor de pimentão.

\section{Introduction}

Sweet pepper (Capsicum annuum L.) is cultivated and consumed around the world. Its major producers are United States, Mexico, Italy, Japan, India and Brazil, where this crop has economic importance (Silva et al., 1999; Nannetti, 2001). Although it can be cultivated in open fields, in tropical climates, sweet pepper is largely grown in greenhouses, where its cycle is extended, leading to rises in productivity. Due to its tropical origin, sweet pepper is especially susceptible to cold seasons at the seedling stage, though fruit set is higher at milder temperatures $\left(19^{\circ} \mathrm{C}\right.$ to $\left.21^{\circ} \mathrm{C}\right)$ (Reifschneider, 2000).

Cultivating sweet pepper in greenhouses also allows production all year round, best management practices, better fruit quality control, lesser or no use of pesticides, earlier harvesting and superior uniformity of fruits (Reifschneider, 2000; Nannetti, 2001).

Interest in sweet pepper pollination has been risen recently, due to the need for adequate pollination levels in an environment such as greenhouses, where insects including floral visitors are excluded. Sweet pepper flowers, like those of most cultivated Solanaceae, are pendent from leaf axils, show a white corolla, five to seven stamens containing 1.0 to $1.5 \mathrm{mg}$ of pollen, and one central style with a round sticky stigma on its top. Anthers are tubular, and dehiscence occurs through lateral opening. Both flower anthesis and anther dehiscence take place in the morning, between $7 \mathrm{~h}$ and 9h (Silva et al., 1999; Dag \& Kammer, 2001; Cruz, 2003). Although sweet pepper flowers are largely self-pollinated, it seems that introducing pollinators such as bees have a 
positive effect on fruit quality (McGregor, 1976; Jarlan et al., 1997). Rasmussen (1985) studied sweet pepper plants and assessed the use of manual pollination, electric pollination, and pollination using the solitary bee Megachile rotundata, and concluded that these three pollination methods resulted in better fruit set than using self-pollination.

There are few studies on sweet pepper pollination (Shipp et al., 1994; Jarlan et al., 1997; Meisels \& Chiasson, 1997; Dag \& Kammer, 2001), and the role of stingless bees in setting fruits of this crop is unknown. However, Heard (1999) stated that flowers of sweet pepper may be partially pollinated by stingless bees. This assertion was reinforced by Free (1993), who also reported workers of Trigona angustula visiting flowers of sweet pepper in Brazil, and listed this stingless bee species as a potential pollinator of $C$. annuum. The stingless bee Melipona subnitida Ducke (Hymenoptera: Apidae) is an endangered endemic species in NE Brazil, and its use as crop pollinator could help to preserve the species (Zanella, 1999).

This study aimed at investigating the potential use of stingless bee Melipona subnitida to pollinate flowers of sweet pepper grown in greenhouse.

\section{Material and Methods}

The research was carried out from September 2002 to January 2003, in the Agrarian Science Centre of Universidade Federal do Ceará, in Fortaleza, Ceará, Northeastern Region of Brazil (3०44'26" S and 38³4'30" W, $19.5 \mathrm{~m}$ above sea level).

Experiments were run in a $165.5 \mathrm{~m}^{2}$ greenhouse, where 306 sweet pepper plants of the variety All Big were introduced in clay pots, spaced $0.60 \times 0.40 \mathrm{~m}$. The greenhouse was divided in two equal parts, where one half was occupied by plots using restricted pollination treatment, and the other half was occupied by the remaining treatments together with two M. subnitida colonies. Clay pots contained organic matter with naturally enriched soil mixed with cattle manure, in a proportion of $50 \%$ each one. Moreover, plants received $10 \mathrm{~g}$ of an equal mixture of urea and potassium chlorate, and $7 \mathrm{~g}$ of simple superphosphate per pot.

All Big is an open pollination variety largely used by small growers. Two colonies of $M$. subnitida Ducke were placed in the greenhouse, when sweet pepper plants begun blossoming, and after a seven-day period of adaptation, experiments were initiated by marking 226 flower buds before anthesis, to be used in four treatments, as described below.

In the hand cross-pollination, 50 flower buds were marked and bagged with fine muslin bags (mesh $1 \times 1 \mathrm{~mm})$. After anthesis, flowers were unbagged and hand-pollinated with pollen from flowers of other plants, by touching the flower stigma with a stamen of fresh dehisced pollen grains. Then, flowers were rebagged. Hand self-pollination consisted of the same procedure described above, and used 66 flowers, differing only in the fact that pollen grains of the same plant was used. In the treatment pollination by bees, each one of the 60 marked flowers were unbagged until it received one $M$. subnitida visit, then the flower was rebagged to prevent further visitation. Restricted pollination (selfpollination) consisted of 50 bagged flowers.

Five parameters were evaluated in this experiment: fruit set, fruit weight, fruit size, average number of seeds per fruit and percentage of fruit malformation. Fruit set was checked 15 days after flower manipulation. Fruits at maturation stage (approximately 30 days after pollination) were weighed, and malformed fruits were counted. The length and width of each fruit was measured with a paquimeter, and then the fruits were opened and the number of seeds was counted.

Fruit weight, fruit size and number of seeds data were analyzed using ANOVA, and means were compared by Tukey test. Fruit set and fruit malformation data were analyzed using a nonparametric Kruskal-Wallis test, due to the binomial character of data (set fruit $=1$ and no set fruit $=0$, or normal $=1$ and malformed $=0$ ). The experimental design was in random blocks and all trials were submitted to the same conditions.

\section{Results and Discussion}

The four pollination treatments tested in this experiment set fruits, and there were no significant differences $\left(\chi^{2}=1.843, \mathrm{df}=3, \mathrm{p}>0.05\right)$ among them (Table 1). Fruit set originating from flower visits by Melipona subnitida did not differ from any of the other three treatments tested in this experiment. Although not a surprising outcome, since sweet pepper is a self-pollinated species (McGregor, 1976; Rasmussen, 1985), increments in productivity following bee visits have been reported in other autogamous crops, such as cotton (Gossypium hirsutum), beans (Phaseolus vulgaris) and tomatoes (Lycopersicum esculentum) (Spangler \& Moffett, 1977; Cribb, 1990; Dag \& Kammer, 2001). Ruijter et al. (1991) 
did not also find increments in fruit set of greenhouse sweet pepper, using honey bees (Apis mellifera) as pollinators. Self-pollination in sweet pepper seems to be sufficient to maximise fruit production, and the use of pollinating agents cannot increase the number of fruits set.

There were significant differences on the weight of fruits from the four treatments. Hand cross-pollination and pollination by bees produced heavier fruits than selfpollination (Table 2). Shipp et al. (1994) also worked with greenhouse sweet pepper and found similar results using the solitary bees Osmia cornifrons and Megachile rotundata, and the highly social A. mellifera; Dag \& Kammer (2001) obtained increments in fruit weight, when using either A. mellifera or Bombus terrestris to pollinate greenhouse sweet pepper, compared with a treatment without bees. Thus, it seems that bee visits to sweet pepper flowers are necessary to ensure maximum fruit weight. In this experiment, such result could be expected, because All Big is an open-pollinated variety instead of a homozygous line produced by self-pollination.

Fruit length did not differ among treatments, but fruit diameter showed significant differences between them. The average fruit diameter of hand cross-pollination and pollination by bees treatments were significantly greater than that of the treatment with restricted pollination (Table 2). Jarlan et al. (1997) obtained heavier and longer

Table 1. Sweet pepper (Capsicum annuum L.) fruit set originated from hand self-pollination, hand cross-pollination, pollination by Melipona subnitida and self-pollination (restricted pollination) ${ }^{(1)}$.

\begin{tabular}{lccc}
\hline Treatment & Flowers per & \multicolumn{2}{c}{ Frui set } \\
\cline { 2 - 4 } & treatment(no.) & (no.) & $(\%)$ \\
\hline Hand cross-pollination & 50 & 41 & $82 \mathrm{a}$ \\
Pollination by M. subnitida & 60 & 42 & $70 \mathrm{a}$ \\
Hand self-pollination & 66 & 45 & $68 \mathrm{a}$ \\
Self-pollination & 50 & 37 & $74 \mathrm{a}$ \\
\hline
\end{tabular}

${ }^{(1)}$ Means not followed by the same letter, in a column, differ at $\mathrm{p}<0.05$ $\left(\chi^{2}=1.843, \mathrm{df}=3\right)$. sweet pepper fruits, using the fly Eristalis tenax as pollinator, and Shipp et al. (1994) observed increments in the proportion of large and extra-large sweet pepper fruits following visits by $O$. cornifrons, $M$. rotundata or A. mellifera. Because the shape of sweet pepper fruits varies according to the variety, it is possible that fruits of some varieties could be affected differently by the type of pollination they receive.

The number of seeds per fruit differed significantly between treatments. Hand cross-pollination, pollination by bees and hand self-pollination treatments showed higher number of seeds than restricted pollination (Table 2). Similar result was observed by Meisels \& Chiasson (1997), in the pollination of sweet pepper flowers by $B$. impatiens, in greenhouse. Increments in the number of seeds per fruit, after using bees as pollinators, are well documented in the literature for different crops (Williams et al., 1987; Free, 1993; Richards, 2001). In the case of the All Big sweet pepper variety, our results showed that seed growers could use M. subnitida to increase seed production.

Seeds play an important role in fruit setting process, since bad developed fruits are the result of an unequal seed distribution inside the fruit (Janick, 1966). Thus, in a well-pollinated flower occurs a rapid development of ovary, and the fecundated seeds produce plant growth hormones, leading to a good fruit development. However, auxin stimuli on the establishment of fruits are related to pollen itself, and to ovary production that is stimulated by pollination (Ferri, 1985).

There were significant differences in the percentage of malformed fruits among the four treatments (Table 3). Fruits originating from the hand cross-pollination and pollination by bees treatments showed the lower number of malformed fruits $\left(\chi^{2}=13.09, \mathrm{df}=3, \mathrm{p}<0.05\right)$. Some authors (Tukey, 1936; Free, 1993) have shown that inadequate pollination increases percentage of malformed fruits. Various causes can be pointed out for inadequate pollination such as insufficient pollen

Table 2. Number of seeds per fruit, weight, length and diameter of sweet pepper (Capsicum annuum L.) fruits originated from hand self-pollination, hand cross-pollination, pollination by Melipona subnitida and self-pollination (restricted pollination)(1).

\begin{tabular}{|c|c|c|c|c|c|}
\hline Treatment & Fruits (no.) & Seeds per fruit (no.) & Fruit weight (g) & Fruit length $(\mathrm{cm})$ & Fruit diameter $(\mathrm{cm})$ \\
\hline Hand cross-pollination & 41 & $135.95 \pm 8.05 \mathrm{a}$ & $55.53 \pm 2.77 \mathrm{a}$ & $5.88 \pm 0.17 \mathrm{a}$ & $5.22 \pm 0.13 a$ \\
\hline Pollination by $M$. subnitida & 42 & $137.83 \pm 9.44 a$ & $53.16 \pm 2.71 \mathrm{a}$ & $5.72 \pm 0.14 \mathrm{a}$ & $5.40 \pm 0.10 \mathrm{a}$ \\
\hline Hand self-pollination & 27 & $126.52 \pm 12.91 \mathrm{a}$ & $47.86 \pm 2.68 \mathrm{ab}$ & $5.60 \pm 0.21 \mathrm{a}$ & $5.09 \pm 0.18 \mathrm{ab}$ \\
\hline Self-pollination & 37 & $74.16 \pm 6.75 b$ & $40.99 \pm 2.83 b$ & $5.66 \pm 0.18 \mathrm{a}$ & $4.88 \pm 0.11 b$ \\
\hline
\end{tabular}

(1) Means not followed by the same letter, in the columns, differ at $\mathrm{p}<0.05$ (Tukey-b test). 
Table 3. Percentage of malformed sweet pepper (Capsicum annuum L.) fruits originated from hand self-pollination, hand cross-pollination, pollination by Melipona subnitida and selfpollination (restricted pollination) ${ }^{(1)}$.

\begin{tabular}{lcc}
\hline Treatment & Fruits (no.) & Malformed fruits (\%) \\
\hline Hand cross-pollination & 32 & $13 \mathrm{a}$ \\
Pollination by M. subnitida & 59 & $17 \mathrm{a}$ \\
Hand self-pollination & 33 & $45 \mathrm{~b}$ \\
Self-pollination & 50 & $48 \mathrm{~b}$ \\
\hline
\end{tabular}

(1)Means not followed by the same letter, in a column, differ at $\mathrm{p}<0.01$ $\left(\chi^{2}=13.09\right.$, df $\left.=3\right)$

deposition on stigma, low pollen viability or compatibility, environmental or nutritional conditions, water shortage etc. In our experiment, temperatures inside the greenhouse were elevated (up to $33^{\circ} \mathrm{C}$ ), but all treatments were under these same conditions, and low percentage of malformed fruits, observed in the treatments hand cross-pollination and pollination by bees, showed that temperature was not detrimental to fruit quality.

The effect of number of pollen grains deposited, and pollen compatibility in seed set and fruit quality should be better studied in this crop. The treatments hand crosspollination and pollination by bees (M. subnitida) produced the higher number of seeds set and lower percentage of malformed fruits, suggesting that a great number of viable, compatible pollen was placed on the flower stigmas. Hand self-pollination also set a high number of seeds, but produced a high percentage of deformed fruits, while self-pollination set the smaller number of seeds and produced a high percentage of malformed fruits, in accordance to Ruijter et al. (1991).

It probably happens because $M$. subnitida deposited a great number of viable pollen grains on the stigmas of sweet pepper flower, assuring many seeds set per fruit. More seeds developing inside each fruit would lead to bigger and heavier fruits, and reduce the percentage of malformed ones.

\section{Conclusion}

1. The use of $M$. subnitida as greenhouse sweet pepper pollinator cannot increase fruit set.

2. M. subnitida is a very efficient species to increase fruit weight, number of seeds and to reduce fruit malformation, if compared to the traditional system of greenhouse cultivation of sweet pepper without bees.

\section{Acknowledgements}

To Ms. M.J. Jales, for her help in the greenhouse work; to Funcap, to Capes and to CNPq, for supporting this research and for grants conceded.

\section{References}

CRIBB, D. Pollination of tomato crops by honeybees. Bee Craft, v.72, p.228-231, 1990.

CRUZ, D.O. Uso e eficiência da abelha jandaíra (Melipona subnitida Ducke) na polinização do pimentão (Capsicum annuum L.) sob cultivo protegido. 2003. 62p. Dissertação (Mestrado) - Universidade Federal do Ceará, Fortaleza.

DAG, A.; KAMMER, Y. Comparison between the effectiveness of honey bee (Apis mellifera) and bumble bee (Bombus terrestris) as pollinators of greenhouse sweet pepper (Capsicum annuum). American Bee Journal, v.141, p.447-448, 2001.

FERRI, M.G. Fisiologia vegetal. São Paulo: EPU, 1985. 401p.

FREE, J.B. Insect pollination of crops. $2^{\text {nd }}$ ed. London: Academic, 1993. 684p.

HEARD, T.A. The role of stingless bees in crop pollination. Annual Review of Entomology, v.44, p.183-206, 1999.

JANICK, J. A ciência da horticultura. Rio de Janeiro: Usaid, 1966. 485p.

JARLAN, A.; OLIVEIRA, D. de; GINGRAS, J. Pollination of sweet pepper (Capsicum annuum L.) in greenhouse by the syrphid fly Eristalis tenax L. Acta Horticulturae (ISHS), v.437, p.335-340, 1997.

McGREGOR, S.E. Insect pollination of cultivated crop plants. Washington, DC: USDA, 1976. 411p. (USDA agriculture handbook, 496).

MEISELS, S.; CHIASSON, H. Effectiveness of Bombus impatiens Cr. as pollinators of greenhouse sweet peppers (Capsicum annuum L.). Acta Horticulturae (ISHS), v.437, p.425-430, 1997.

NANNETTI, D.C. Nitrogênio e potássio aplicados via fertirrigação na produção, nutrição e pós-colheita do pimentão. 2001. 184p. Tese (Doutorado) - Universidade Federal de Lavras, Lavras.

RASMUSSEN, K. Pollination of pepper: results from two years experiment. Gartner Tidende, v.101, p.830-831, 1985.

REIFSCHNEIDER, F.J.B. (Org.). Capsicum - pimentas e pimentões no Brasil. Brasília: Embrapa-SNT; Embrapa-CNPH, 2000. 133p.

RICHARDS, A.J. Does low biodiversity resulting from modern agricultural practice affect crop pollination and yield? Annals of Botany, v.88, p.165-172, 2001.

RUIJTER, A. de; EIJNDE, J. van den; STEEN, J. van der. Pollination of sweet pepper (Capsicum annuum L.) in greenhouses by honey bees. Acta Horticulturae (ISHS), v.228, p.270-274, 1991.

SHIPP, J.L.; WHITFIELD, G.H.; PAPADOPOULOS, A.P. Effectiveness of the bumble bee, Bombus impatiens Cr. (Hymenoptera: Apidae), as a pollinator of greenhouse sweet pepper. Scientia Horticulturae, v.57, p.29-39, 1994. 
SILVA, M.A.G. de; BOARETO, A.E.; MELO, A.M.T. de; FERNANDES, H.M.G.; SCIVITTARO, W.B. Rendimento e qualidade de frutos de pimentão cultivado em ambiente protegido, em função do nitrogênio e potássio aplicados em cobertura. Scientia Agricola, v.56, p.1199-1207, 1999.

SPANGLER, H.G.; MOFFETT, J.O. Honey bee visits to tomato flowers in polyethylene greenhouses. American Bee Journal, v.117, p.580-582, 1977.

TUKEY, H.B. A relation between seed attachment and carpel symmetry and development in Prunus. Science, v.84, p.513-515, 1936.
WILLIAMS, I.H.; MARTIN, A.P.; WHITE, R.P. The effect of insect pollination on plant development and seed production in winter oilseed rape (Brassica napus L.). Journal of Agricultural Science, v.109, p.135-139, 1987.

ZANELLA, F.C.V. Apifauna da caatinga (NE do Brasil): biogeografia histórica, incluindo um estudo sobre a sistemática, filogenia e distribuição das espécies de Caenonomada Ashmead, 1899 e Centris (Paracentris) Cameron, 1903 (Hymenoptera, Apoidea, Apidea). 1999. 162p. Tese (Doutorado) - Universidade de São Paulo, Ribeirão Preto.

Received on October 13, 2004 and accepted on May 2, 2005 